\title{
Participation of the Immune System and Hedgehog Signaling in Neoangiogenesis Under Laser Photobiomodulation
}

\author{
Ana Cristina Gonzalez ${ }^{1}$, Elisângela Trindade Santos ${ }^{1}$, Tila Fortuna Costa Freire ${ }^{2 *}$, Maíra Ferreira Sá , Zilton de \\ A. Andrade ${ }^{3}$, Alena R. A. P. Medrado \\ ${ }^{1}$ Immunology department, Federal University of Bahia, Salvador, Bahia, Brazil \\ ${ }^{2}$ Basic Sciences Department, Bahiana School of Medicine and Public Health, Salvador, Bahia, Brazil \\ ${ }^{3}$ Experimental Pathology Laboratory of Gonçalo Moniz Research Center - FIOCRUZ, Salvador, Bahia, Brazil
}

\section{*Correspondence to \\ Tila Fortuna Costa Freire, \\ Department of Basic Sciences \\ Rua Silveira Martins, $\mathrm{n}^{\circ} 3386$ \\ Cabula, Salvador, Bahia, Brazil \\ CEP: $41150-100$ \\ Tel: +55(71)32578200 \\ Email: tilafortuna@gmail.com}

Published online October 1, 2019

\begin{abstract}
Introduction: This study aimed to characterize immune and endothelial cells, myofibroblasts and pericytes, and positive cells for hedgehog proteins in late tissue repair of rats skin wounds treated with $670 \mathrm{~nm}$ photobiomodulation therapy (PBMT).

Methods: A blind experimental study was conducted, in order to assess the effect of PBMT in later stages of healing, with emphasis on neoangiogenesis, immune cells and Hedgehog signaling. Forty Wistar rats were allocated randomly in two groups; control and treated with a diode GaAlAs laser $\left(9 \mathrm{~mW}, 670 \mathrm{~nm}, 0.031 \mathrm{~W} / \mathrm{cm}^{2}\right.$, spot size of $0.28 \mathrm{~cm}^{2}$, fluence of $4 \mathrm{~J} /$ $\mathrm{cm}^{2}$ applied every other day, until a total dose of $16 \mathrm{~J} / \mathrm{cm}^{2}$ was achieved). Standardized skin wounds were performed and the animals were euthanized at 14, 21, 28 and 35 days. Tissue sections were subjected to hematoxylin-eosin and immunohistochemistry for CD31, NG2, smooth muscle alpha actin, CD8, CD68, Ptch, Gli-2 and Ihh. All histomorphometric data were statistically analyzed and significance level was at $P<0.05$.

Results: At late stages of wound healing, neoangiogenesis persisted as revealed for the number of $\mathrm{CD} 31+$ cells $(P=0.016)$ and $\mathrm{NG} 2+$ and smooth muscle alpha actin positive pericytes $(P=0.025)$, for both experimental groups. By day 21, laser-treated group had decreased CD68+ cells $(P=0.032)$ and increased CD8+ $(P=0.038)$. At remodeling stage, there were positive cells for the hedgehog signaling pathway family which seemed to be activated.

Conclusion: These data suggest that photobiomodulation therapy was able to modulate extracellular matrix remodelling even at the later stages of wound healing.

Keywords: Wound healing; Low-level light therapy; Immunohistochemistry; Neoangiogenesis.
\end{abstract}

\section{Introduction}

Recent studies have shown that laser photobiomodulation (LPBM) accelerates the acute phase of inflammation, stimulates cell proliferation, increases the contraction of skin wounds, and accelerates re-epithelialization..$^{1-4}$ Does LPBM also modulate the later phases of wound healing? Although few studies have investigated this matter, ${ }^{1,5}$ the answer to this question is still unclear because the duration of the benefits derived from LPBM can be perpetuated in irradiated tissues.

At the end of wound healing, when the epithelial layer is recomposed and the process is considered complete, there is evidence that cellular and molecular changes persist for a variable length of time. ${ }^{6}$ For instance, persistence of neoangiogenesis and immunoregulatory cells in the tissue have been described. ${ }^{7}$ However, to date, studies about LPBM have focused on the early stages of tissue repair. ${ }^{2,3}$

Medrado et $\mathrm{al}^{1}$ have described the changes in collagen biosynthesis and proliferation of alpha-actin positive cells in later stages of skin repair of rats treated with a $670 \mathrm{~nm}$ diode laser. They suggested that the maturation of collagen fibers and neoangiogenesis perpetuated even 60 days after cutaneous surgery. Based on these preliminary results, we hypothesized that LPBM could act as a biomodulatory agent on endothelial and immune cells and could activate the Hedgehog signaling pathway, albeit at a later stage of the tissue repair.

The hedgehog signaling pathway has been identified through genetic studies in Drosophila and is conserved in vertebrates. ${ }^{8}$ Shh (Sonic), Ihh (Indian), and Dhh (Desert) are the 3 known binders of the Hedgehog family $(\mathrm{HH})$. For signaling to occur, the activities of 2 transmembrane proteins, Ptch (Patched) and Smo (Smoothed) are also necessary. Ptch is considered as the primary receptor and Smo the co-receptor, the activation of Smo, is essential for signal transduction. This co-receptor moves

Please cite this article as follows: Gonzalez AC, Santos ET, Freire TFC, Sá MF, Andrade ZA, Medrado ARAP. Participation of the immune system and hedgehog signaling in neoangiogenesis under laser photobiomodulation. J Lasers Med Sci. 2019;10(4):310-316. doi:10.15171/ jlms.2019.50. 
to the top of the primary cilia, and when activated, it initiates a series of intracellular events resulting in the stabilization of a transcription factor called Gli which induces the transcription of proteins that are essential for morphogenesis and histodifferentiation. ${ }^{9}{ }^{10}$ Hedgehog signaling is involved in many processes of embryonic development, including morphogenesis, angiogenesis, and repair. ${ }^{10,11}$ However, its action on skin repair has not been studied yet.

This study aims to characterize, through histological and histomorphometric analysis, the immune and the endothelial cells, myofibroblasts and pericytes, and the positive cells of Hedgehog proteins in the late phase of tissue repair of rat skin wounds treated with $670 \mathrm{~nm}$ LPBM.

\section{Materials and Methods}

\section{Experimental Groups}

Forty male Wistar rats, Rattus norvegicus, weighing between 200-300 g were kept in individual cages under controlled temperature, humidity, and lighting. They received a standard commercial diet and water ad libitum.

All the procedures were in accordance with Fortuna et al. ${ }^{4}$ Anesthesia was administered intraperitoneally with a combination of ketamine $(50 \mathrm{mg} / \mathrm{kg})$ and xylazine $(10 \mathrm{mg} /$ $\mathrm{kg}$ ) at a dose of $0.2 \mathrm{~mL} / 100 \mathrm{~g}$ of body weight. Then, the animals were shaved on the dorsal region and an iodophor was used as a sanitizer (Biochemistry, Rio de Janeiro, Brazil). A standardized tissue fragment was removed from the skin with a circular $8 \mathrm{~mm}$ punch (Stiefel Biopsy Punch, Germany). The wounds were not sutured. After the removal of surgical tissue, animals were maintained in individual cages and inspected daily for bleeding, loss of crust, and the presence of any kind of exudate.

The animals were randomly distributed into 2 experimental groups by means of their registered laboratory number.

Laser Group: Animals were irradiated with a semiconductor laser device, namely a continuous-wave $\left(9 \mathrm{~mW}, 670 \mathrm{~nm}, 0.031 \mathrm{~W} / \mathrm{cm}^{2}\right)$ diode laser of gallium aluminum arsenide (ALGaAs), with a $0.28 \mathrm{~cm}^{2}$ active tip area (Laser VR-KC-610, Dentoflex, Brazil). There was an everyday application of $1 \mathrm{~J} / \mathrm{cm}^{2}$ at 4 equidistant points from the circular wound border, totaling $4 \mathrm{~J} / \mathrm{cm}^{2}$ per session. This type of application proceeded until a total dose of $16 \mathrm{~J} / \mathrm{cm}^{2}$ was reached. The irradiation time was 31 seconds per point and 124 seconds per session.

Control Group: The animals were subjected to contact with the active tip of a low-level laser device, without light emission, in the same pattern as described for the laser group.

Animals from both groups were euthanized on days 14 , 21,28 , and 35 after surgery in a $\mathrm{CO}_{2}$ chamber.

Histopathology

Skin tissue from the damaged area was removed and fixed in $4 \%$ buffered formalin solution with $\mathrm{pH}$ of 7.4 for 24 hours. Tissue samples were subjected to further histological processing and embedding in paraffin blocks.

Paraffin-embedded tissue samples were cut using a microtome and $4 \mu \mathrm{m}$ sections were obtained. They were stained with hematoxylin-eosin (HE).

\section{Immunohistochemistry}

Slides were pre-treated with organosilane-based adhesive (3-Aminopropyltriethoxiysilane, Sigma, St. Louis, MO, USA). All the antibodies used in the study were standardized (Anti-CD31/1:1000, SC-1506, Santa Cruz Biotech; Anti Ptch1/1:1000, NB200-118, Novus Biological; Anti-Gli-2/1:1000, GWB-CE7858, GenWay Biotech; Anti-Ihh/1:250, AB 39634, Abcam; AntiNG2/1:200, MAB 5384, Millipore; Anti-Actina/1:200, M0851, DakoCytomation; Anti-CD8/1:10, AR0801, Biosource; Anti-CD68/1:200, MCA341R, AbD Serotec). The peroxidase method was used for immunoblotting. Histological sections were subjected to deparaffinization in xylene and rehydrated by treatment with absolute ethanol and then with water at room temperature $\left(23^{\circ} \mathrm{C}\right)$. Antigen retrieval was performed with a $10 \mathrm{mM}$ citrate buffer at $\mathrm{pH}$ of 6.0 in a $96^{\circ} \mathrm{C}$ water bath and subsequent blocking of endogenous peroxidase using Dako Dual Enzyme Block (DAKO, Carpinteria, CA, USA). To eliminate non-specific binding, a serum-free protein block (DAKO, Carpinteria, CA, USA) was used and the sections were incubated at $4^{\circ} \mathrm{C}$ with primary antibodies in a humidified chamber overnight. The sections were further incubated with a secondary antibody, Dako envision polymer peroxidase (Dako, Carpinteria, CA, USA), for 30 minutes at room temperature. The reaction was revealed using DAB (Dako, Carpinteria, CA, USA) with a $3 \%$ hydrogen peroxide solution. The slides were counterstained with Harris hematoxylin and mounted with Canada balsam.

A qualitative and quantitative graduation was adopted to indicate the intensity of the immunohistochemical reaction in which zero was considered non-reactive. The other levels were + (discrete) ++ (moderate) and +++ (severe).

\section{Histomorphometry}

Histological and immunohistochemical analysis of all sections was performed without prior knowledge of the groups to which the animals belonged. The area containing standard positive staining cells was measured by morphometry and the results were tabulated and subjected to statistical analysis. The morphometric study was performed using images captured by Motic Images Advanced 3.0 software. A standard area was used to analyze all cases (12288.000 000 pixels). Five areas of each section were analyzed. Adobe Photoshop CS5 Extended software version 12.0 x32 (Adobe Systems Incorporated, USA) was used to measure the percentage of stained 
tissue. Then, these data were compared to the total area selected. All examinations were performed doubleblinded to avoid bias.

\section{Statistical Analysis}

A database was created in Microsoft Excel (2010) and data were analyzed using $\mathrm{R}$ software (version 3.1.3), where a descriptive analysis was obtained (median and quartiles) to identify the general and specific characteristics of the study sample. The Shapiro-Wilk test was used to verify the normal distribution of data. According to this analysis, the variables were analyzed using the non-parametric student's $t$ test and the Mann-Whitney test was used for independent samples. The significance level for this study was $5 \%(P<0.05)$.

\section{Results}

14 Days

The experimental groups showed intense cellularity on the wounded area corresponding to fibroplasia. Spindle and rhomboid-shaped cells with intense basophilia were seen near the blood capillaries. The laser group exhibited neoangiogenesis with basophilic cells proliferating from the wall of vascular endothelium to the extracellular matrix. These cells were smooth muscle alpha actin and NG2 positive cells. The presence of monomorphonuclear cells, $\mathrm{CD}^{+}$and $\mathrm{CD}^{+} 8^{+}$, was observed in both experimental groups $(P>0.05)$. There were more $\mathrm{CD} 31^{+}$cells in the control group than in the laser group $(P<0.05)$. Alpha smooth muscle cell actin and $\mathrm{NG}^{+}$cells were more numerous in the control group; however, this data was statistically significant only for smooth muscle alpha actin positive cells $(P<0.001)$ (Table 1$)$.

Components of the hedgehog pathway showed the more expressive distribution of $\mathrm{Ihh}^{+}$and $\mathrm{Ptch}^{+}$cells than Gly-2 ${ }^{+}$cells in both control and laser groups, mainly in fusiform cells present in the extracellular matrix (Figure 1). However, when the two groups were compared, the differences were not significant $(P>0.05)$.

\section{Days}

Similar features to those described in the 14 days' section were observed after 21 days. Rhomboid-shaped cells were more concentrated below the epidermis, near the basal membrane. In the control group, few vessels were seen. There was mild inflammatory infiltrate composed of lymphocytes and plasma cells in the reticular dermis. In the laser group, the blood vessels were congested.

During this period, the presence of monomorphonuclear cells increased. There was a higher level of $\mathrm{CD}^{+}$cells in the control group $(P=0.038)$. The laser group showed fewer $\mathrm{CD} 8^{+}$cells $(P=0.032)$. There were also a greater number of $\mathrm{CD} 31^{+}$cells in the laser group compared with the control group $(P=0.016)$ (Table 1; Figure 2).

The cells identified as myofibroblasts and pericytes and positive stained smooth muscle alpha actin and the NG2 cells were observed in the extracellular matrix of the control group $(P=0.025$ and $P<0.05$ respectively) (Table 1).

There was a higher number of Gli-2+ and $\mathrm{Ihh}^{+}$cells in the control group. Moreover, an inverse relationship was observed regarding the $\mathrm{Ptch}^{+}$cells, although these differences were not statistically significant $(P>0.05)$ (Table 2).

Table 1. Immunohistochemical Expression of CD8, CD31, CD68, Smooth Muscle Alpha Actin, and NG-2

\begin{tabular}{|c|c|c|c|c|c|c|c|c|c|c|}
\hline & \multicolumn{10}{|c|}{ Antibody } \\
\hline & $\mathrm{CD}-8^{\mathrm{a}}$ & & CD-31 ${ }^{b}$ & & CD-68 ${ }^{b}$ & & aActina $^{\text {a }}$ & & NG-2 ${ }^{b}$ & \\
\hline & Median (Q1/Q3) & $\boldsymbol{P}$ & Median (Q1/Q3) & $P$ & Median (Q1/Q3) & $P$ & Median (Q1/Q3) & $P$ & Median (Q1/Q3) & $P$ \\
\hline 14d Laser & $\begin{array}{c}21.1 \\
(14.2 ; 47.3)^{\mathrm{A}}\end{array}$ & & $42.2(15.1 ; 55.0)^{\mathrm{AB}}$ & & $71.7(37.1 ; 84.6)^{\mathrm{A}}$ & & $\begin{array}{c}32.5 \\
(18.4 ; 46.5)^{* A}\end{array}$ & & $\begin{array}{c}215.0 \\
(83.0 ; 1077.7)^{\mathrm{B}}\end{array}$ & \\
\hline $14 \mathrm{~d}$ Control & $\begin{array}{c}38.9 \\
(28.1 ; 111.5)^{\mathrm{A}}\end{array}$ & & $62.9(49.8 ; 75.3)^{\mathrm{AB}}$ & & $49.8(44.9 ; 73.1)^{\mathrm{A}}$ & & $\begin{array}{c}206.4 \\
(182.6 ; 227.4)^{\mathrm{A}}\end{array}$ & 0.001 & $\begin{array}{c}548.2 \\
(256.5 ; 839.8)^{\mathrm{AB}}\end{array}$ & \\
\hline 21d Laser & $\begin{array}{c}110.8 \\
(91.3 ; 130.4)^{A}\end{array}$ & & $\begin{array}{c}1196.0 \\
(475.4 ; 3379)^{* A}\end{array}$ & & $58.3(48.6 ; 87.1)^{* A}$ & & $50.9(21.4 ; 80.6)^{* A}$ & & $\begin{array}{c}288.7 \\
(206.9 ; 1060.1)^{A B}\end{array}$ & \\
\hline $21 \mathrm{~d}$ Control & $66.4(43.9 ; 92.6)^{\mathrm{A}}$ & 0.038 & $\begin{array}{c}55.3 \\
(13.3 ; 100.7)^{\mathrm{AB}}\end{array}$ & 0.016 & $\begin{array}{c}101.0 \\
(88.7 ; 435.6)^{\mathrm{A}}\end{array}$ & 0.032 & $\begin{array}{c}117.4 \\
(83.8 ; 151.0)^{\mathrm{A}}\end{array}$ & 0.025 & $\begin{array}{c}950.0 \\
(487.4 ; 2980.9)^{A B}\end{array}$ & \\
\hline 28d Laser & $\begin{array}{c}180.1 \\
(29.2 ; 210.8)^{A}\end{array}$ & & $16.3(6.5 ; 26.1)^{\mathrm{B}}$ & & $\begin{array}{c}98.1 \\
(64.2 ; 142.3)^{\mathrm{A}}\end{array}$ & & $37.1(11.9 ; 99.7)^{\mathrm{A}}$ & & $\begin{array}{c}3814.2 \\
(1772.5 ; 5855.9)^{A}\end{array}$ & \\
\hline 28d Control & $41.4(28.2 ; 54.7)^{\mathrm{A}}$ & & $\begin{array}{c}16.8 \\
(11.3 ; 44.8)^{\mathrm{AB}}\end{array}$ & & $\begin{array}{c}54.4 \\
(34.7 ; 76.7)^{\mathrm{A}}\end{array}$ & & $8.2(2.6 ; 15.6)^{\mathrm{A}}$ & & $\begin{array}{c}708.9 \\
(262.2 ; 2217.5)^{A B}\end{array}$ & \\
\hline $35 d$ Laser & $29.7(12.6 ; 70.3)^{A}$ & & $4.1(1.8 ; 31.9)^{\mathrm{AB}}$ & & $\begin{array}{c}96.2 \\
(25.2 ; 209.2)^{\mathrm{A}}\end{array}$ & & $28.8(17.6 ; 61.7)^{\mathrm{A}}$ & & $185.5(42.9 ; 614.3)^{\mathrm{AB}}$ & \\
\hline $35 \mathrm{~d}$ Control & $29.2(8.6 ; 67.9)^{\mathrm{A}}$ & & $\begin{array}{c}23.8 \\
(11.1 ; 75.9)^{\mathrm{AB}}\end{array}$ & & $\begin{array}{c}36.0 \\
(11.1 ; 70.2)^{\mathrm{A}}\end{array}$ & & $10.7(8.9 ; 80.5)^{\mathrm{A}}$ & & $362.3(164.2 ; 569.4)^{\mathrm{AB}}$ & \\
\hline
\end{tabular}

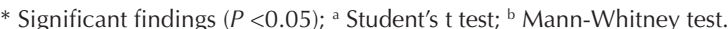

Different letters represent significant findings $(P<0.05)$ between groups in each variable studied $(\mathrm{A}, \mathrm{B})$ [among groups $21 \mathrm{~d}$ and laser $28 \mathrm{~d} C D-31$ antibody $(P=$ $0.014)$ and $14 \mathrm{~d}$ and $28 \mathrm{~d}$ Laser NG-2 antibody $(P=0.014)]$. 


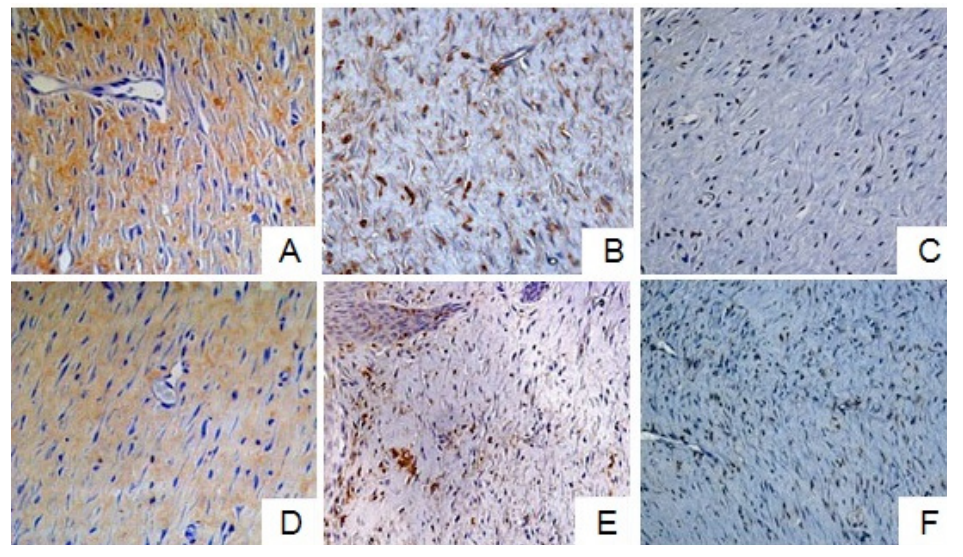

Figure 1. Immunohistochemical expression of Ptch cells in the extracellular matrix (A) and Ihh (B), and Gli-2 (C) individual positive cells arranged in the area of fibroplasia in the control and laser groups (D, E, F). Immunohistochemistry, anti-Ptch, anti-Ihh, and anti-Gli, X 400.

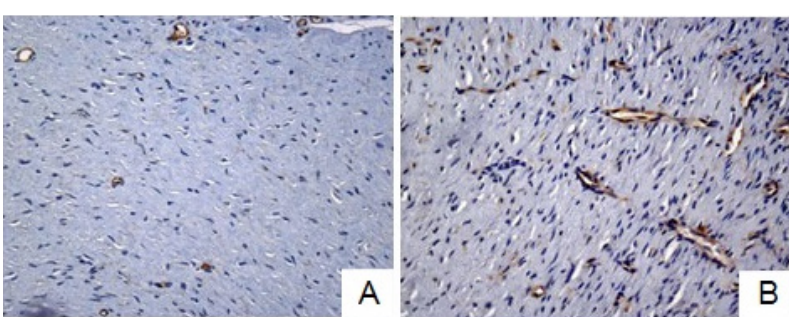

Figure 2. $\mathrm{CD} 31^{+}$cells delimited blood capillaries in the control group (A) and the laser group (B). There were more CD31+ cells around small capillaries in the laser group after 21 days. Immunohistochemistry, anti-CD31, X200.

\section{Days}

There was a decrease in cellularity in the dermis in both groups, although a significant concentration of basophilic cells was observed, sometimes fusiform and/ or rhomboid, in the subepithelial area in the laser-treated group. Few blood vessels were seen in the reticular dermis. Although monomorphonuclear inflammatory cells were more common in the laser group, the difference was not significant $(P>0.05)$.

The number of $\mathrm{CD} 1^{+}$cells was similar in both experimental groups. However, in the laser group, the CD $31^{+}$cells significantly decreased compared to the previous study period $(P=0.014)$ (Table 1$)$.

The expression of the $\mathrm{NG}^{+}$cells was higher on day 28 (Figure 3 ) compared to day $14(P=0.014)$ Table 1$)$. However, when the experimental groups were compared at this period, there was no significant difference in the smooth muscle alpha actin positive cells and the NG2 ${ }^{+}$ cells, and in the Gli-2 $2^{+}$and $\mathrm{Ihh}^{+}$cells between both groups $(P>0.05)$ (Table 2).

\section{Days}

The tissue sections obtained from the laser-treated and control groups showed extensive areas of fibroplasia, absence of skin appendages, and a reduced number of $\mathrm{CD}^{+}$and $\mathrm{CD}^{+} 8^{+}$cells $(P>0.05)$ (Table 1$)$.

The $\mathrm{CD} 31^{+}$cells in the laser group were lower than those in the control group, although the difference was not statistically significant $(P>0.05)$. There was also no statistically significant difference in the presence of the smooth muscle alpha actin positive cells between the groups, although the laser group showed a higher number. An inverse relationship was observed for the

Table 2. Expression of Gli-2+ $\mathrm{Ihh}^{+}$and $\mathrm{Ptch}^{+}$cells in the control and laser groups

\begin{tabular}{|c|c|c|c|}
\hline & \multicolumn{3}{|c|}{ Antibody } \\
\hline & Gli-2 & Ihh & Ptch \\
\hline & Median (Q1-Q3) & Median (Q1-Q3) & Median (Q1-Q3) \\
\hline $14 \mathrm{~d}$ Laser & $80.7(46.9 ; 92.3)$ & $24766.7(12244.1 ; 35553.7)$ & $1601.2(951.2 ; 1926.9)$ \\
\hline $14 \mathrm{~d}$ Control & $89.0(52.4 ; 126.9)$ & $29467.4(19660.6 ; 39274.2)$ & $1166.2(546.4 ; 2516.7)$ \\
\hline $21 \mathrm{~d}$ Laser & $79.0(53.0 ; 117.5)$ & $19532.3(15532.6 ; 32332.3)$ & $1776.0(1171.2 ; 2380.9)$ \\
\hline $21 \mathrm{~d}$ Control & $117.0(77.5 ; 160.3)$ & $30602.2(15532.6 ; 32332.3)$ & $1516.7(674.1 ; 1888.6)$ \\
\hline $28 \mathrm{~d}$ Laser & $152.6(92.9 ; 188.2)$ & $12462.2(5836.0 ; 31550.7)$ & $598.2(358.5 ; 904.8)$ \\
\hline $28 \mathrm{~d}$ Control & $98.5(72.3 ; 130.7)$ & $12623.4(11743.4 ; 17011.3)$ & $1021.1(521.7 ; 1481.3)$ \\
\hline $35 \mathrm{~d}$ Laser & $134.4(127.3 ; 180.9)$ & $5057.7(4471.7 ; 14524.5)$ & $1574.8(1221.9 ; 2520.7)$ \\
\hline $35 \mathrm{~d}$ Control & $125.4(86.0 ; 159.1)$ & $10537.2(8720.6 ; 18883.4)$ & $1698.2(666.7 ; 3390.9)$ \\
\hline
\end{tabular}



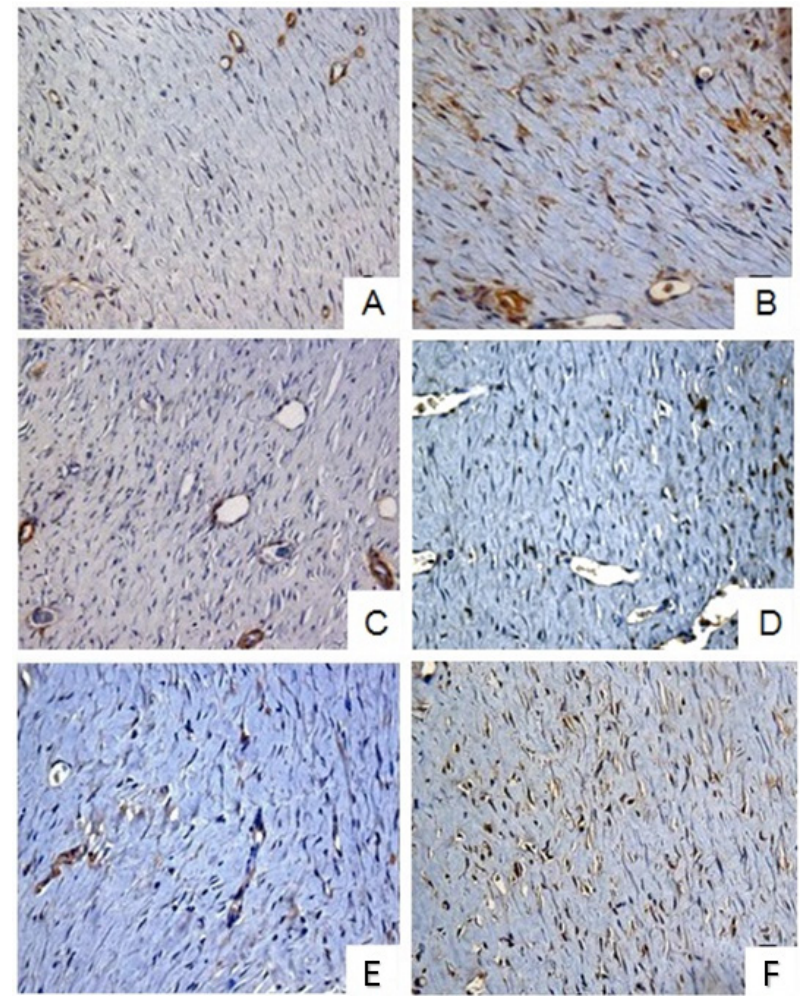

Figure 3. Smooth muscle alpha actin positive cells (A) and $\mathrm{NG} 2+$ cells (B) in tissue sections obtained from the control animal (21 days) and the laser-treated animal (C, D) respectively. Immunohistochemical expression of NG2 in the perivascular cells in the wounded area in the control animal (E) and the lasertreated animal (F) after 28 days. Immunohistochemistry, antimuscle alpha actin anti-NG2, X 200.

$\mathrm{NG}^{+}$cells, although it was not statistically significant $(P>0.05)$ (Table 1).

The number of Gli2 ${ }^{+}$cells was higher in the laser group but the $\mathrm{Ihh}^{+}$and $\mathrm{Ptch}^{+}$cells predominated in the control group $(P>0.05)$. The Gli-2 $2^{+}$cells were numerous only in the laser group on day 35 compared to days 14 and 21 $(P>0.05)$ (Table 2).

\section{Discussion}

There is increasing evidence that cellular, biochemical and molecular mechanisms that take place in wound healing often perpetuate themselves for a longer period during tissue repair. ${ }^{6}$ The final clinical aspect of an injury may not reflect simultaneous biological phenomena going on in the tissue. The present study aimed to characterize the populations of immunocompetent cells, myofibroblasts, pericytes, and other cell types that provide phenotypic evidence of hedgehog signaling pathway expression in later stages of tissue repair. In addition, the study investigated whether the primary effects triggered by LPBM could influence the course of biological events as the day advanced.

The experimental model of cutaneous wound healing in rats has been used to investigate the different stages of repair. ${ }^{12}$ In particular, the action of possible endogenous and exogenous factors as biomodulating agents has been considered. LPBM is an example of such a biomodulating factor. ${ }^{13,14}$ In a study conducted by Medrado et al, ${ }^{13} 670$ $\mathrm{nm}$ diode lasers were used on cutaneous ulcers in rats, and a significant increase in the trans-differentiation of myofibroblasts was observed during the early phase of wound healing. However, the authors investigated only the initial days of repair. Later in 2008, the same authors $^{1}$ evaluated cutaneous healing aggravated by the action of silica until 60 days after the induction of the same standardized skin wound. Although there were no statistically significant differences between the experimental groups in the later periods of repair, on 30th and 60th days, it was observed that neoangiogenesis persisted until the 60th day. Could LPBM modulate the course of this process and some cellular populations during the later phase of repair? To answer this question, the present study was conducted from day 14 to day 35 .

On day 14 , the number of $\mathrm{CD}^{+}$cells were smaller in the laser group. This finding confirmed that the potent antiinflammatory action of LPBM was prolonged. ${ }^{15,16}$ There is evidence from in vivo and in vitro studies that $\mathrm{CD}^{+}$ T lymphocytes can also exert regulatory effects. ${ }^{14}$ Boyce et $\mathrm{al}^{17}$ showed an increase in CD8 $\mathrm{T}$ cell suppressors in later stages of healing and suggested their involvement in the process, probably mediated by the release of Th-1 cytokines/growth factors. Although it was not the aim of the present study to evaluate the cytokine profile produced by such cells in situ, our results demonstrated an increase in $\mathrm{CD}^{+}$cell counts from day $21(P=0.038)$ to day 28 in the laser group. The number of $\mathrm{CD}^{+} 8^{+}$cells was smaller on day 21 in the laser group $(P<0.005)$. Probably, the regulatory action of $\mathrm{CD}^{+}$lymphocytes caused a decrease in $\mathrm{CD}^{+} 8^{+}$cells. Some studies have shown the role of LPBM in macrophage activity at the beginning of wound healing, but the presence of these cells have not yet been investigated in later stages of repair. ${ }^{18} \mathrm{We}$ can suggest that the inflammatory response that takes place in the early phase of wound repair indeed extends into later stages of this process, even when the wound is clinically healed.

The expression of smooth muscle alpha actin, biomodulated by phototherapy, has previously been investigated. ${ }^{19}$ Although the presence of smooth muscle alpha actin indicates the trans-differentiation of fibroblasts to myofibroblasts, other cell types can also express such a biomarker. Medrado et $\mathrm{al}^{14}$ suggested that myofibroblasts present in tissue sections of laser-treated animals could be derived from perivascular cells (pericytes) or pre-existing fibroblasts in the extracellular matrix since these cells have the simultaneous expression of NG2, smooth muscle alpha actin, and desmin during healing. The authors suggested that the maximum contraction of the wound occurred on day 7 as laser-irradiated animals exhibited a significant increase in myofibroblasts and pericytes in the newly formed dermis. In the current study, there was no 
significant difference between the experimental groups. The control group had more NG2 and alpha smooth actin positive cells in all periods of the study. This fact seems to indicate that wound contraction occurs later in the control animals than in the laser-treated animals. The roles played by smooth muscle alpha actin and $\mathrm{NG}^{+}$cells in the wound bed cover a broad spectrum of biological processes such as collagen production and repopulation of tissues as well as their respective essential structures and functions. ${ }^{20}$

The formation of new capillaries from the pre-existing ones is an essential component of healing due to an increased demand for nutrients. ${ }^{7}$ According to Andrade, ${ }^{21}$ angiogenesis is a biological process that has a positive impact on wound remodeling. In this study, maximum neoangiogenesis occurred on day 21 and increased in the animals irradiated with lasers $(\mathrm{p}<0.05)$. The remaining vessels in the micro-environment of the injury during this period may contribute to ensuring not only an increased supply of oxygen and nutrients, but also local cell repopulation. ${ }^{22}$ Besides, several studies have shown that proliferating pericytes may protrude from the wall of the capillary and accumulate in the damaged tissues where they turn into myofibroblasts and begin to synthesize the extracellular matrix. ${ }^{23}$

The Hedgehog pathway is involved in many aspects of embryonic development, including morphogenesis, angiogenesis, and repair. ${ }^{11}$ Its role in repair is still a relatively unexplored topic. There was no significant difference between the control and laser groups regarding $\mathrm{Ihh}^{+}, \mathrm{Gli}^{+}$, and $\mathrm{Ptch}^{+}$cells in the present study. According to Athar et $\mathrm{al}^{24}$ the transducer protein, Shh, has been demonstrated to be the most active protein in cutaneous healing. It is necessary to consider the possibility that the activation of Hedgehog signaling may be an early event in wound healing. As only later phases of repair were studied in our research, our understanding of how these proteins regulate the entire process is limited. Sicklick et $\mathrm{al}^{25}$ reported that myofibroblasts could produce Hedgehog ligand which controls tissue reconstruction and remodeling. This binder can also regulate the viability and migratory activity of various cell types stimulated by Hedgehog signaling. Thus, additional investigations to evaluate the expression of transducer signal proteins of this family upon skin repair are necessary.

The findings of this study suggest that LPBM slightly continue to modulate extracellular matrix remodeling during later experimental wound healing. While primary action of lasers on first days of repair is well known, it can persist over time in the micro-environment of the lesion, though the effects may be discrete or even imperceptible from a clinical point of view. Further studies in this area, which evaluate the expression of these and other signaling proteins through techniques that are more sensitive and other experimental models, would contribute to the elucidation of late biological events related to the action of LPBM in wound healing.

\section{Ethical Considerations}

The experimental research was conducted according to the laws of the Gonçalo Moniz Research Center, Fiocruz, with the approval of the Institutional Animal Care and Use Committee under the protocol number 010/11.

\section{Conflict of Interests}

The authors declare no conflict of interest.

\section{References}

1. Medrado AP, Soares AP, Santos ET, Reis SR, Andrade ZA. Influence of laser photobiomodulation upon connective tissue remodeling during wound healing. $J$ Photochem Photobiol B. 2008;92(3):144-52.

2. Reis SR, Medrado AP, Marchionni AM, Figueira C, Fracassi LD, Knop LA. Effect of 670-nm laser therapy and dexamethasone on tissue repair: a histological and ultrastructural study. Photomed Laser Surg. 2008;26(4):30713.

3. Loreti EH, Pascoal VL, Nogueira BV, Silva IV, Pedrosa DF. Use of laser therapy in the healing process: a literature review. Photomed Laser Surg. 2015;33(2):104-16. doi:10.1089/pho.2014.3772

4. Fortuna T, Gonzalez AC, Ferreira MS, Reis SR, Medrado AA. Biomodulatory potential of low-level laser on neoangiogenesis and remodeling tissue. A literature review. J Public Health Dent. 2018;9(1):95-103. doi: 10.17267/25963368

5. Fortuna T, Gonzalez AC, Sá MF, Andrade ZD, Reis SR, Medrado AR. Effect of $670 \mathrm{~nm}$ laser photobiomodulation on vascular density and fibroplasia in late stages of tissue repair. Int Wound J. 2018;15(2):274-82. doi: 10.1111/ iwj.12861

6. Velnar T, Bailey T, Smrkolj V. The wound healing process: an overview of the cellular and molecular mechanisms. J Int Med Res. 2009;37(5):1528-42. doi:10.1177/147323000903700531

7. Delavary BM, van der Veer WM, van Egmond $M$, Niessen FB, Beelen RH. Macrophages in skin injury and repair. Immunobiology. 2011;216(7):753-62. doi: 10.1016/j. imbio.2011.01.001

8. Ingham PW, Nakano Y, Seger C. Mechanisms and functions of Hedgehog signalling across the metazoa. Nat Rev Genet. 2011 Jun;12(6):393. doi: 10.1038/nrg2984.

9. Byrd N, Grabel L. Hedgehog signaling in murine vasculogenesis and angiogenesis. Trends Cardiovas Med. 2004;14(8):308-13. doi: 10.1016/j.tcm.2004.09.003

10. Gonzalez AC, Ferreira M, Ariel T, Reis SR, Andrade Z, Peixoto Medrado A. Immunohistochemical evaluation of hedgehog signalling in epithelial/mesenchymal interactions in squamous cell carcinoma transformation: a pilot study. $J$ Oral Pathol Med. 2016;45(3):173-9. doi:10.1111/jop.12346

11. Bielefeld KA, Amini-Nik S, Alman BA. Cutaneous wound healing: recruiting developmental pathways for regeneration. Cell Mol Life Sci . 2013;70(12):2059-81. doi: 10.1007/s00018-012-1152-9

12. Gál P, Vidinský B, Toporcer T, Mokrý M, Mozeš Š, Longauer F, et al. Histological assessment of the effect 
of laser irradiation on skin wound healing in rats. Photomed Laser Surg. 2006;24(4):480-8. doi:10.1089/ pho.2006.24.480

13. Medrado AR, Pugliese LS, Reis SR, Andrade ZA. Influence of low level laser therapy on wound healing and its biological action upon myofibroblasts. Laser Surg Med. 2003;32(3):239-44. doi:10.1002/lsm.10126

14. Medrado A, Costa T, Prado T, Reis S, Andrade Z. Phenotype characterization of pericytes during tissue repair following low-level laser therapy. Photodermatol Photoimmunol Photomed. 2010;26(4):192-7. doi: 10.1111/j.16000781.2010.00521.x

15. Catão MHCV. The benefits of low intensity laser in oral diseases practice. Rev Bras Patol Oral. 2004;3(4):214-218. [In Portuguese]

16. Barbul AD, Breslin RJ, Woodyard JP, Wasserkrug HL, Efron GE. The effect of in vivo T helper and T suppressor lymphocyte depletion on wound healing. Ann Surg. 1989;209(4):479-483. doi: 10.1097/00000658-19890400000015

17. Boyce DE, Jones WD, Ruge F, Harding KG, Moore K. The role of lymphocytes in human dermal wound healing. Br J Dermatol. 2000;143(1):59-65. doi:10.1046/j.13652133.2000.03591.x

18. Souza NH, Ferrari RA, Silva DF, Nunes FD, Bussadori SK, Fernandes KP. Effect of low-level laser therapy on the modulation of mitochondrial activity of macrophages. Braz J Phys Ther. 2014;18(40):308-314. doi:10.1590/bjptrbf.2014.0046

19. Houreld NN, Ayuk SM, Abrahamse H. Expression of genes in normal fibroblasts cells (WS1) in response to irradiation at $660 \mathrm{~nm}$. J Photochem Photobio B. 2014; 130:146-152. doi:10.1016/j.jphotobiol.2013.11.018

20. Cherng S, Young J, Ma H. Alpha-smooth muscle actin (a-SMA). J Am Sci 2008;4(4):7-9. doi:10.5935/16789741.20150081

21. Andrade ZA. A double and paradoxical role for angiogenesis. Rev Patol Trop. 2013;42(3): 259-264.

22. Tazima MFGS, Vicente YAMV, Moriya T. Biology and Wound Healing. Simp Fund Clin Cir 2008;41(3):259-264. [Portuguese].

23. Lee JS, Semela D, Iredale J, Shah VH. Sinusoidal remodelling and angiogenesis: a new function for the liverspecific pericyte. J Hepatol. 2007; 45:817-825. doi: 10.1002/ hep. 21564.

24. Athar M, Tang X, Lee JL, Kopelovich L, Kim AL. Hedgehog signalling in skin development and cancer. Exp Dermatol. 2006;15:667-677. doi: 10.1111/j.1600-0625.2006.00473.x

25. Sicklick JK, Li YX, Jayaraman A, Kannangai R, Qi Y, Vivekanandan P, et al. Dysregulation of the Hedgehog pathway in human hepatocarcinogenesis. Carcicogenesis. 2005;27(4):748-757. doi: 10.1093/carcin/bgi292 